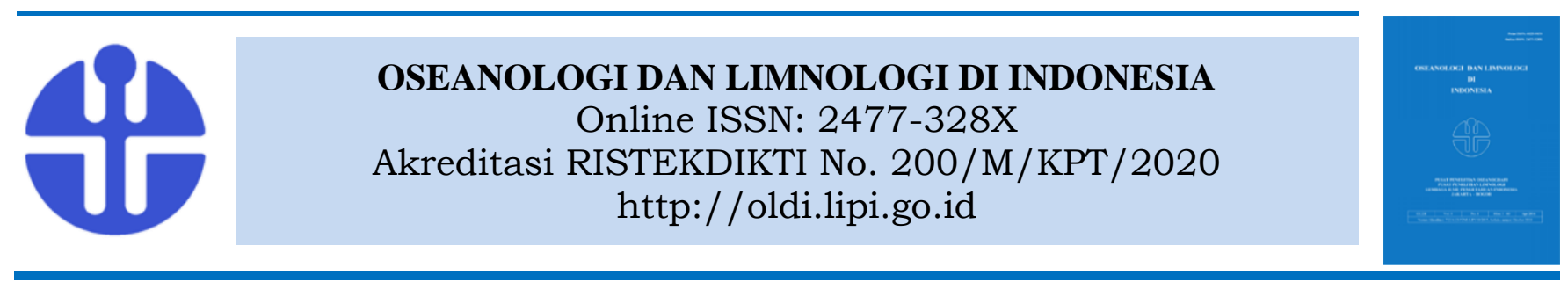

\title{
Kelimpahan Dinoflagellata Bentik Berbahaya di Habitat Lamun dan Makroalga di Pulau Pari, Kepulauan Seribu, Indonesia
}

\section{Mochamad Ramdhan Firdaus ${ }^{1}$, Arief Rachman', Oksto Ridho Sianturi' ${ }^{1}$, Diah Anggraini Wulandari $^{2}$, Hanny Meirinawati ${ }^{1}$, Mariana Destila Bayu Intan ${ }^{1}$, \& Edy Endrotjahyo ${ }^{1}$}

\author{
${ }^{1}$ Pusat Riset Oseanografi, Badan Riset dan Inovasi Nasional (BRIN), ${ }^{2}$ Pusat Riset Bioteknologi, Badan Riset \\ dan Inovasi Nasional (BRIN)
}

Email: ramdhan.ekologi@gmail.com

Submitted 7 October 2021. Reviewed 13 October 2021. Accepted 14 December 2021. DOI: 10.14203/oldi.2021.v6i3.382

\begin{abstract}
Abstrak
Dinoflagellata bentik merupakan bagian dari fungsi ekosistem dasar perairan. Namun keberadaan dinoflagellata penghasil senyawa racun ciguatoxin (CTX) penyebab penyakit Ciguatera Fish Poisoning (CFP) merupakan ancaman bagi kehidupan biota laut dan manusia di kawasan pesisir kepulauan, seperti di Pulau Pari. Penelitian ini bertujuan untuk mempelajari kelimpahan lima genus dinoflagellata bentik berbahaya dan beracun, yaitu Amphidinium, Coolia, Gambierdiscus, Ostreopsis, dan Prorocentrum di dua tipe habitat di Pulau Pari, yaitu habitat makroalga dan lamun. Pengambilan sampel dinoflagellata bentik dilakukan pada Juni 2019 menggunakan substrat buatan berupa kasa berukuran $10 \times 15 \mathrm{~cm}$. Selain itu dilakukan pengukuran beberapa parameter lingkungan seperti kandungan nutrien (nitrogen dan fosfat) dan suhu. Dari hasil penelitian, diketahui bahwa rata-rata kelimpahan sel dinoflagellata di habitat lamun lebih tinggi empat kali lipat dibandingkan di habitat makroalga. Genus Gambierdiscus diketahui paling melimpah di habitat lamun, sedangkan Prorocentrum paling melimpah di habitat makroalga. Analisis Kelompok Utama (AKU) menunjukkan bahwa rasio nitrogen-fosfor $(\mathrm{N}: \mathrm{P})$ merupakan faktor yang paling berpengaruh terhadap sebagian besar genus target dalam penelitian ini, kecuali Ostreopsis yang diketahui melimpah di habitat makroalga yang kaya kandungan fosfor $(\mathrm{P})$. Adanya peningkatan densitas dinoflagellata bentik beracun hingga tujuh kali lipat dalam kurun waktu 6-7 tahun sejak penelitian terdahulu di tahun 2012 dan 2013 menunjukkan pertambahan tingkat gangguan dan tekanan pada habitat makroalga dan lamun di Pulau Pari. Hal tersebut membutuhkan perhatian khusus untuk menghindari terjadinya kasus Marak Alga Berbahaya (MAB) dan CFP akibat ledakan populasi dinoflagellata bentik beracun di perairan Pulau Pari.
\end{abstract}

Kata kunci: dinoflagellata bentik, amphidinium, coolia, gambierdiscus, ostreopsis, prorocentrum, lamun, rumput laut, nutrien

\begin{abstract}
The Abundance of the Harmful Benthic Dinoflagellate in the Seagrass and Macroalgae Habitats on Pari Island, Thousand Islands, Indonesia. Benthic dinoflagellates are an important part of benthic ecosystems and part of their ecological functions. However, ciguatoxin (CTX) producer dinoflagellates, which could cause Ciguatera Fish Poisoning (CFP) disease, is a known threat to marine biota and the island's coastal communities, such as in Pari Island. Thus, this research aimed is to study the population of five harmful and toxin producer benthic dinoflagellate genera, namely Amphidinium, Coolia, Gambierdiscus, Ostreopsis, and Prorocentrum, in macroalgae and seagrass habitats of Pari Island. Benthic dinoflagellate samples were collected in Juni 2019 using artificial substrates in the form of a $10 \times 15 \mathrm{~cm}$ nylon
\end{abstract}


Firdaus et al.

screen. Environmental variables, such as nutrient concentration (nitrogen and phosphorus) and water temperature were also measured. The results showed that the average benthic dinoflagellate density in seagrass habitats was four times higher compared to the macroalgae habitats. Gambierdiscus were found as the most abundant benthic dinoflagellate in seagrass habitats, while Prorocentrum were more abundant in macroalgae habitats. Principal Component Analysis (PCA) showed that the N:P ratio was the most important regulating parameter for most benthic dinoflagellate genera in this study, except Ostreopsis, which was found to be more abundant in phosphorus-rich macroalga habitats. The data also shows an increase of benthic dinoflagellate cell density up to seven times compared to the previous research data in 2012 and 2013. That trend indicates an increase in the disturbance and pressure on the macroalgae and seagrass habitats of Pari Island, which require special attention to prevent the occurrence of toxic Benthic Harmful Algal Blooms (bHABs) and CFP cases in the island.

Keywords: benthic dinoflagellate, amphidinium, coolia, gambierdiscus, ostreopsis, prorocentrum, seagrass, macroalgae, nutrients

\section{Pendahuluan}

Dinoflagellata bentik merupakan salah satu produsen primer penting di ekosistem laut pesisir (Thoha, 2008; Hoppenrath et al., 2014). Di kawasan perairan tropis, kelompok mikroalga tersebut umum ditemukan hidup menempel pada substrat seperti batu, sedimen, lamun, dan terumbu karang mati, serta diketahui memiliki peran penting dalam regulasi sistem trofik di ekosistem dasar perairan (benthic ecosystem) (Okolodkov et al., 2007). Namun, beberapa genus dinoflagellata bentik juga diketahui dapat menyebabkan terjadinya fenomena Marak Alga Berbahaya (MAB), atau Harmful Algal Blooms (HABs) (Larsen \& Mohammad-Noor, 2012). Selain itu, genus dinoflagellata bentik, seperti Gambierdiscus, diketahui dapat menghasilkan senyawa racun (toksin) ciguatoxin (CTX) yang dapat berbahaya bagi organisme laut dan manusia (Hoppenrath et al., 2014). Melalui rantai makanan, toksin dinoflagellata dapat mengalami bioakumulasi pada biota lain seperti ikan (Randall, 1958; deSylva, 1994) dan saat dikonsumsi manusia dapat menyebabkan gejala keracunan yang disebut dengan Ciguatera Fish Poisoning (CFP) (Hoppenrath et al., 2014). Selain Gambierdiscus, genus dinoflagellata bentik lain yang diketahui memiliki spesies penghasil toksin penyebab penyakit CFP antara lain adalah Ostreopsis, Prorocentrum, Coolia, dan Amphidinium (Almazan-Becerril et al., 2015). Tingginya densitas dinoflagellata bentik beracun di dasar perairan pesisir beberapa negara kawasan Pasifik dan Atlantik diketahui telah mengakibatkan setidaknya 50.000 orang mengalami kasus CFP setiap tahunnya akibat mengkonsumsi ikan bernilai ekonomi penting yang telah terkontaminasi oleh senyawa racun CTX (Soliño \& Costa, 2020). Jumlah tersebut masih akan terus bertambah akibat meluasnya distribusi spesies dinoflagellata bentik beracun penyebab CFP, seperti spesies dari genus Gambierdiscus, ke berbagai perairan pesisir negara-negara sub-tropis (temperate) sebagai salah satu efek dari pemanasan global (global warming) (Soliño \& Costa, 2020). Mengingat potensi dampak CFP yang besar kepada manusia, maka penelitian mengenai distribusi dan kelimpahan dinoflagellata bentik beracun menjadi penting untuk dilakukan di Indonesia. Oleh karena itu, penelitian ini dilakukan di Pulau Pari yang berada di dalam kawasan Kepulauan Seribu, dengan memfokuskan pada lima genus target dinoflagellata bentik yang diketahui dapat menghasilkan senyawa racun CTX, yaitu Gambierdiscus, Prorocentrum, Ostreopsis, Coolia, dan Amphidinium.

Pulau Pari yang menjadi lokasi penelitian ini merupakan salah satu pulau kecil di gugusan Kepulauan Seribu yang terletak di sebelah barat laut kota metropolitan Jakarta dan diketahui memiliki beberapa ekosistem unik seperti terumbu karang, padang lamun, dan hutan mangrove (Marfai et al., 2018). Keanekaragaman ekologis kawasan pesisir Pulau Pari menyebabkan pulau tersebut menjadi salah satu destinasi ekowisata yang berkembang dengan pesat di kawasan Kepulauan Seribu (Marfai et al., 2018). Meskipun demikian, peningkatan aktivitas manusia secara umum di Pulau Pari dapat mengganggu fungsi dan keberlangsungan berbagai ekosistem pesisir di Pulau Pari. Pulau Pari juga termasuk salah satu kawasan di Kepulauan Seribu yang rentan terhadap pencemaran yang diakibatkan oleh tumpahan minyak (Nurfitri et al., 2018). Selain itu, sebagai bagian dari Kepulauan Seribu, Pulau Pari juga berhadapan dengan Teluk Jakarta yang memiliki tingkat pencemaran bahan organik tinggi akibat berbagai limbah domestik kota Jakarta yang terbawa masuk oleh sungai. Tingginya cemaran bahan organik dapat meningkatkan unsur 
hara di perairan (eutrofikasi) yang dapat memicu terjadinya ledakan populasi fitoplankton merugikan terutama yang berasal dari kelompok Dinoflagellata (Thoha, 2007).

Penelitian mengenai dinoflagellata bentik telah dilakukan di Kepulauan Seribu, yaitu di Pulau Pari, Pulau Harapan, Pulau Tidung, Pulau Penjaliran, dan Pulau Pramuka (Widiarti, 2002; Widiarti, 2007; Widiarti et al., 2012; Anggraeni et al., 2013; Razi et al., 2014; Thoha et al., 2020; Widiarti \& Pudjiarto, 2015). Salah satu temuan penting dari penelitian-penelitian tersebut adalah adanya pengaruh jenis substrat terhadap kelimpahan dan jenis dinoflagellata bentik yang menempel. Widiarti (2002) misalnya menemukan bahwa pada ekosistem terumbu karang Pulau Penjaliran, substrat yang paling banyak digunakan oleh dinoflagellata bentik untuk menempel adalah makroalga. Razy et al. (2014) juga meneliti dinoflagellata bentik pada ekosistem terumbu karang Pulau Harapan dan mereka menemukan bahwa Gambierdiscus toxicus hanya memiliki spesifitas substrat terhadap makroalga saja, sedangkan Ostreopsis sp. memiliki spesifitas beberapa substrat sekaligus, yaitu lamun, karang, pasir, dan makroalga. Selain itu, penelitian terdahulu di Pulau Pari pada tahun 2013 menemukan adanya dominasi Prorocentrum di komunitas dinoflagellata bentik yang ditemukan di empat tipe substrat, yaitu lamun, karang terumbu, makroalga, dan pasir (Thoha et al., 2020).

Meskipun penelitian mengenai dinoflagellata bentik berbahaya dan beracun di Pulau Pari telah cukup banyak dilakukan, namun sebagian besar hanya terfokus pada tiga genus dinoflagellata saja, yaitu Prorocentrum, Gamberdiscus, dan Ostreopsis (Widiarti \& Anggraeni, 2012; Anggraeni et al., 2013; Thoha et al., 2020. ). Dengan demikian data dan informasi mengenai distribusi dan kelimpahan dua genus dinoflagellata beracun lainnya, yaitu Amphidinium dan Coolia, di berbagai tipe habitat di Pulau Pari masih sangat minim. Oleh karena itu, penelitian ini bertujuan untuk mempelajari kelimpahan dan distribusi lima genus dinoflagellata bentik beracun, yaitu Gambierdiscus, Prorocentrum, Ostreopsis, Coolia, dan Amphidinium, di dua tipe habitat utama di Pulau Pari, yaitu lamun dan makroalga. Selain itu, penelitian ini bertujuan untuk mempelajari dinamika populasi dinoflagellata bentik di Pulau Pari dengan membandingkan data penelitian terdahulu di tahun 2013 oleh Thoha et al. (2020) dan mempelajari kaitan dinamika populasinya dengan kondisi fisik-kimia perairan di Pulau Pari.

\section{Metodologi}

\section{Lokasi dan Waktu Penelitian}

Penelitian dilakukan pada Juni 2019 di Pulau Pari, Kepulauan Seribu, Indonesia yang berjarak kurang lebih $35 \mathrm{~km}$ di Barat Laut kota Jakarta. Pulau Pari merupakan pulau karang (coral cays) yang terdiri atas empat gugus pulau kecil, yaitu Pulau Burung, Pulau Tikus, Pulau Kongsi, dan Pulau Tengah, dengan luas total daratan sekitar 4 $\mathrm{km}^{2}$ (Maduppa et al., 2012). Pengambilan sampel dalam penelitian ini dilakukan di area yang dipilih berdasarkan kriteria tertentu, yaitu (i) area semi tertutup yang tidak terlalu luas dan (ii) didominasi sekaligus oleh dua tipe habitat berbeda, yaitu makroalga dan lamun. Area pengambilan sampel dalam penelitian ini hanya memiliki panjang sekitar $2 \mathrm{~km}$ dan lebar $0,5 \mathrm{~km}$. Terdapat enam stasiun pengambilan sampel yang berada di area laguna yang terletak di sebelah selatan pulau Pari, dengan jarak antar stasiun kurang dari 500 meter (Gambar 1). Pengambilan sampel dilakukan dengan metode selam permukaan (snorkeling) pada kedalaman 1-3 meter.

\section{Pengambilan dan Ekstraksi Sampel}

Penelitian ini memfokuskan pada lima genus dinoflagellata bentik penghasil senyawa toksin CTX, yaitu Ampidinium, Coolia, Gambierdiscus, Ostreopsis, and Prorocentrum. Selanjutnya kelima genus tersebut disingkat dengan istilah "genus target". Metode pengambilan dan ekstraksi sampel merujuk pada protokol di dalam "YEOSU Project Information and Method: Use of an Artificial Substrate to Assess Field Abundance of Benthic HAB (BHAB) Dinoflagellate" (Kibler \& Litaker, 2012). Sampel diperoleh dengan menggunakan metode substrat buatan berupa kasa (screen) berbahan nilon dengan ukuran $15 \times 10$ $\mathrm{cm}$. Kasa kemudian diikat pada benang nilon yang telah dilengkapi pemberat dan pelampung, agar kasa tersebut dapat mengapung di kolom air dan tidak hanyut terbawa arus. Kasa kemudian diletakan di lokasi penelitian dan dibiarkan selama 24 jam. Setelah 24 jam, kasa dimasukan ke dalam toples berukuran 2 liter beserta dengan air laut yang ikut terbawa. Pemindahan kasa ke dalam toples dilakukan dengan hati-hati tanpa menyentuh kasa. Pada tahapan ini sampel tidak langsung diawetkan, tetapi segera dibawa ke laboratorium lapangan yang telah disiapkan. Di laboratorium, toples dikocok selama 30 menit agar dinoflagellata bentik yang menempel pada kasa terlepas. Air laut di dalam toples lalu disaring menggunakan jaring nilon berbentuk lingkaran dengan diameter $47 \mathrm{~mm}$ dan ukuran mata (mesh size) 17 mikron. Penyaringan 
Firdaus et al.

dilakukan dengan metode vakum menggunakan pompa tangan (handpump) agar sel dinoflagellata tidak rusak akibat tekanan yang berlebihan. Hasil saringan berupa jaring nilon berisi sel dinoflagellata bentik kemudian dipindahkan ke dalam tabung sentrifugasi berukuran $15 \mathrm{~mL}$ dan kemudian diisi dengan akuabides sebanyak 10 $\mathrm{mL}$. Sampel tersebut kemudian diawetkan dengan menambahkan $2 \mathrm{~mL}$ Lugol (Elder \& Elbrachter, 2010).
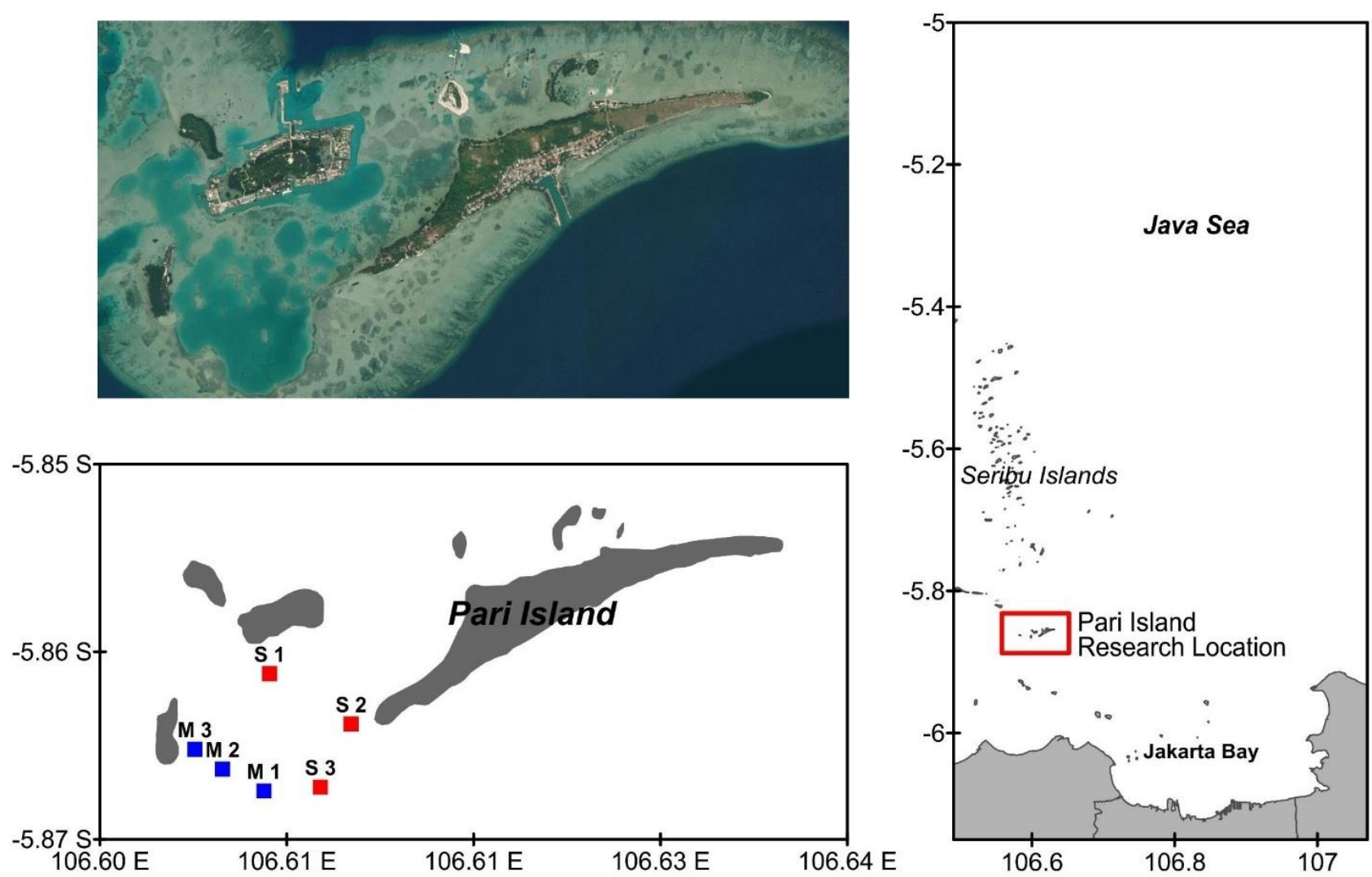

घstasiun penelitian di area

Gambar 1. Peta lokasi penelitian. $\square$ stasiun penelitian di area lamun, makroalga.

Figure 1. Map of the research location. Шresearch stations in seagrass area, "research station in macroalgae area.

\section{Analisis sampel}

Identifikasi dan pencacahan dinoflagellata bentik dilakukan dengan mengambil sebanyak satu mililiter fraksi sampel dari tabung sentrifugasi dengan menggunakan stamp pipette. Fraksi sampel kemudian ditempatkan ke dalam Sedgewick Rafter Counting Chamber (SRCC) dan dianalisis di bawah mikroskop dengan perbesaran 100 - 200x. Jumlah dinoflagellata bentik yang telah diperoleh kemudian dikonversi ke dalam satuan sel/100 $\mathrm{cm}^{2}$. Konversi dilakukan dengan menggunakan persamaan (1) dan (2) sebagai berikut (Kibler \& Litaker, 2012; Moreira \& Tester, 2016):

$$
S=(I / H) \times(I / G) \times(F / N)
$$

Ket:

$\mathrm{S}=$ Densitas spesies A dinoflagellata bentik ( $\mathrm{sel} / \mathrm{g}$ atau $\mathrm{sel} / \mathrm{cm}^{2}$ )
$\mathbf{J}=$ Jumlah sel spesies A dinoflagellata bentik yang terhitung dalam SRCC

$\mathrm{H}=$ Volume fraksi sampel yang diamati dengan SRCC (mL)

$\mathrm{I}=$ Volume final sampel setelah melewati proses filtrasi dan ekstrasi (mL)

$\mathrm{G}=$ Volume sampel yang disaring/difiltrasi $(\mathrm{mL})$

$\mathrm{F}=$ Total volume sampel yang diambil dari lapangan $(\mathrm{mL})$

$\mathrm{N}=$ Berat substrat alami, seperti makroalga/lamun (g); bila menggunakan substrat buatan berupa kasa (screen), gunakan rumus (2) untuk menghitung luas area substrat buatan $\left(\mathrm{cm}^{2}\right)$

$A \Sigma=A x N x+A y N y-N x N y 16 r^{2}$

Ket: 
$\mathrm{Ax}=$ Luas area filamen jaring pada sumbu $\mathrm{x}$ (panjang)

Ay $=$ Luas area filamen jaring pada sumbu y (lebar)

$\mathrm{Nx}=$ Jumlah filamen jaring pada sumbu $\mathrm{x}$

$\mathrm{Ny}=$ Jumlah filamen jaring pada sumbu $\mathrm{y}$

$\mathrm{r}=$ jari-jari filamen

Sebagai catatan, untuk mendapatkan hasil berupa sel $/ 100 \mathrm{~cm}^{2}$ yang digunakan dalam penelitian ini, maka hasil perhitungan $\mathrm{S}$ pada rumus (1) dikalikan dengan 100.

\section{Analisis nutrien}

Analisis nutrien dilakukan untuk mengetahui konsentrasi nitrogen dan fosfat di dalam air. Sebanyak $30 \mathrm{~mL}$ sampel air di lokasi penelitian diambil dan dimasukan ke dalam tabung sentrifugasi. Selanjutnya tabung-tabung berisi sampel ditempatkan di dalam kotak sampel berisi es. Di laboratorium, sampel disaring dengan menggunakan kertas saring selulosa asetat berukuran 0,45 mikron. Selanjutnya, sampel air dianalisis menggunakan Continous Flow Analyzer (The San ++ ) mengacu pada metode dari manual (Skalar, 2016).

\section{Analisis data}

Data penelitian yang telah diperoleh selanjutnya dianalisis secara statistik dengan cara melakukan analisis klastering, analisis korelasi, dan analisis komponen utama (AKU). Ketiga analisis dilakukan masing-masing untuk mengetahui adanya pengelompokan genus dinoflagellata, korelasi antara kelimpahan genusgenus dinoflagellata dengan parameter lingkungan, dan keterkaitan parameter lingkungan secara spesifik terhadap kelimpahan genus-genus target di lokasi penelitian.

\section{Hasil}

Hasil penelitian menunjukkan bahwa lima genus dinoflagellata beracun, yaitu Ampidinium, Coolia, Gambierdiscus, Ostreopsis, dan Prorocentrum ditemukan di lokasi penelitian (Tabel 1). Genus Coolia, Gambierdiscus, dan Prorocentrum ditemukan di setiap stasiun penelitian, genus Amphidinium hanya ditemukan di area komunitas lamun, yaitu di stasiun S2 dan S3. Sedangkan, genus Ostreopsis dapat ditemukan baik di area komunitas lamun maupun makroalga, yaitu di stasiun S2, M1, M2, dan M3. Dengan demikian, di komunitas lamun total terdapat 5 genus target sedangkan di komunitas makroalga terdapat 4 genus target.

Hasil pencacahan menunjukkan bahwa kelimpahan total dinoflagellata bentik di masingmasing stasiun berkisar $714-4.648 \mathrm{sel} / \mathrm{cm}^{2}$ (Gambar 2A). Stasiun dengan kelimpahan tertinggi ditemukan di area lamun, yaitu di stasiun S2, sedangkan stasiun dengan kelimpahan terendah ditemukan di area makroalga, yaitu di stasiun M1. Hasil pencacahan juga menunjukkan bahwa kelimpahan dinoflagellata bentik di area lamun lebih tinggi dibanding area makroalga. Di area lamun, kelimpahan total berkisar antara 2.889 - $4.648 \mathrm{sel} / 100 \mathrm{~cm}^{2}$, sedangkan di area makroalga berkisar antara $714-1.192 \mathrm{sel} / 100 \mathrm{~cm}^{2}$. Jika dilihat dari nilai rata-rata, kelimpahan di area lamun $\left(3.880 \mathrm{sel} / 100 \mathrm{~cm}^{2}\right)$ empat kali lipat lebih tinggi dibanding area makroalga (917 $\mathrm{sel} / 100 \mathrm{~cm}^{2}$ ). Selain itu jumlah sel genus Gambierdiscus, Prorocentrum, dan Coolia yang ditemukan pada ekosistem lamun lebih banyak 310 kali lipat dibanding ekosistem makroalga. Hanya Ostreopsis yang ditemukan lebih banyak di ekosistem makroalga dalam penelitian ini.

Tabel 1. Kehadiran genus Ampidinium, Coolia, Gambierdiscus, Ostreopsis, and Prorocentrum di setiap stasiun penelitian.

Table 1. The presence of the genera Ampidinium, Coolia, Gambierdiscus, Ostreopsis, and Prorocentrum in each research station.

\begin{tabular}{cccccc}
\hline Station & Amphidinium & Coolia & Gambierdiscus & Ostreopsis & Prorocentrum \\
\hline S 1 & - & + & + & - & + \\
S 2 & + & + & + & + & + \\
S 3 & + & + & + & - & + \\
M 1 & - & + & + & + & + \\
M 2 & - & + & + & + & + \\
M 3 & - & + & + & + & + \\
\hline
\end{tabular}

(+) hadir (presence); (-) tidak hadir (absence) 
Firdaus et al.
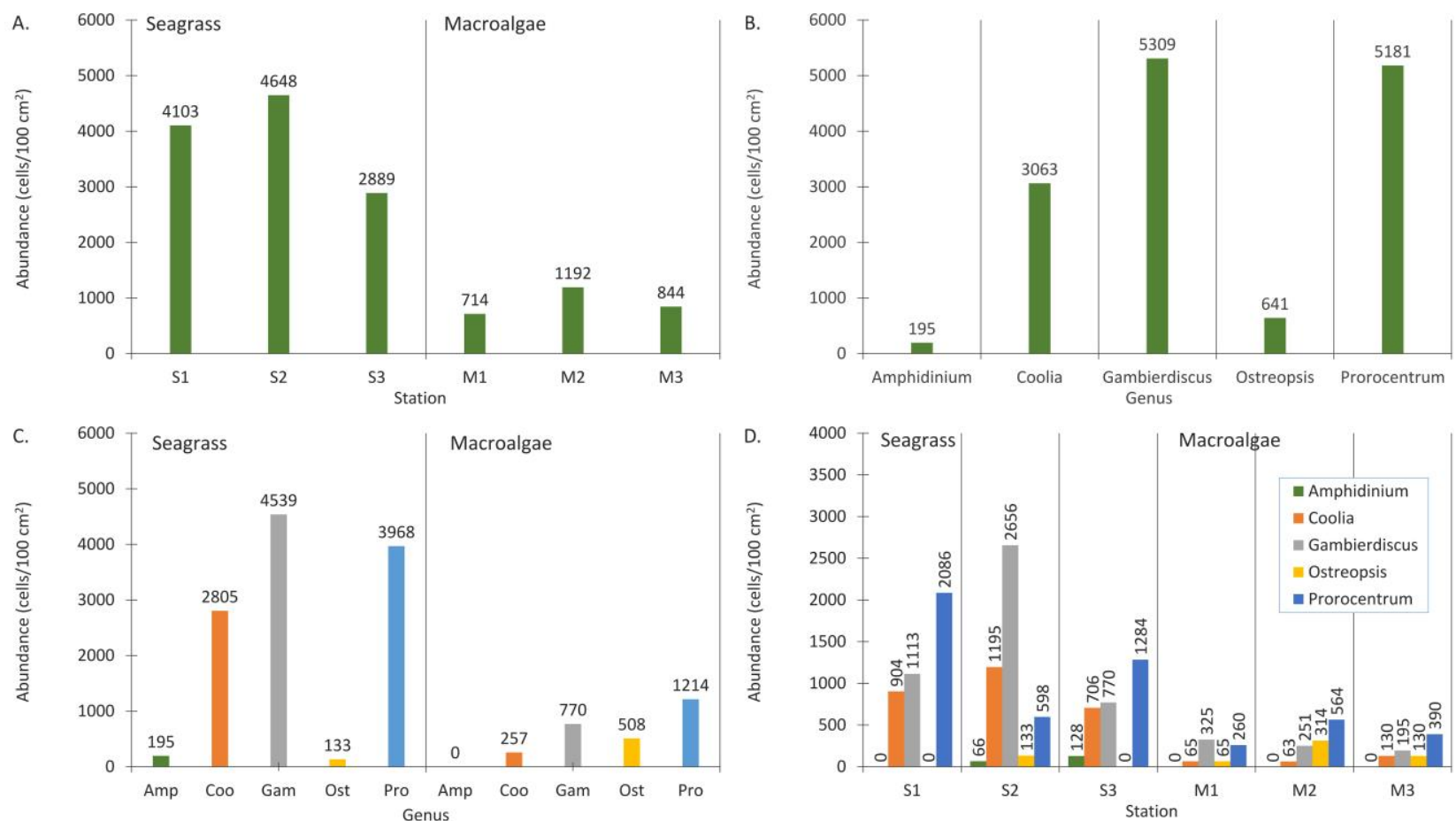

Gambar 2. Kelimpahan total dinoflagellata bentik di masing-masing stasiun (A). Kelimpahan total masingmasing genus dinoflagellata bentik (B). Kelimpahan total masing-masing genus dinoflagellata bentik di ekosistem lamun dan makroalga (C). Kelimpahan total masing-masing genus dinoflagellata bentik di setiap stasiun (D).

Figure 2. Total abundance of benthic dinoflagellates at each station (A). The total abundance of each genus of benthic dinoflagellates (B). Total abundance of each genus of benthic dinoflagellates in the ecosystem of seagrass and macroalgae $(\mathrm{C})$. The total abundance of each genus of benthic dinoflagellates at each station (D).

Kelimpahan total untuk setiap genus dapat dilihat pada Gambar 2B. Genus Gambierdiscus dan Prorocentrum diketahui merupakan dua genus yang paling mendominasi area penelitian dengan masing-masing kelimpahan total sebesar 5.309 sel $/ 100 \mathrm{~cm}^{2}$ dan 5.181 $\mathrm{sel} / 100 \mathrm{~cm}^{2}$. Genus Amphidinium tercatat merupakan genus yang paling sedikit ditemukan dalam penelitian ini. Bahkan genus tersebut hanya ditemukan di area lamun saja, yaitu di stasiun S2 dan S3 (Gambar 2C). Jika dibandingkan antara area lamun dan makroalga, diketahui bahwa genus yang paling mendominasi di kedua area terebut tidaklah sama. Area lamun didominasi oleh genus Gambierdiscus, diikuti oleh Prorocentrum, Coolia, Aphidinium, dan Ostreopsis. Sedangkan area makroalga didominasi oleh genus Prorocentrum, diikuti oleh Gambierdiscus, Ostreopsis, dan Coolia

\section{Analisis Klastering}

Analisis klastering menunjukkan adanya pengelompokan komposisi genus-genus dinoflagellata di area penelitian. Berdasarkan batas minimal similaritas $70 \%$, diketahui bahwa pengelompokan terbagi menjadi tiga kelompok utama di mana kelompok pertama tersebar di area makroalga sedangkan kelompok kedua dan ketiga tersebar di area lamun (Gambar 3). Kelompok makroalga dan lamun memiliki similaritas hanya sebesar 30 persen, meskipun jarak antara kedua area tersebut relatif dekat $(<500 \mathrm{~m})$. Pengelompokan ini menunjukkan adanya pengaruh keberadaan lamun dan makroalga terhadap pembentukan struktur komunitas (shapping of community) dinoflagellata bentik. Variasi komposisi genus-genus target di area lamun dan makroalga juga berbeda. Selain memiliki kelimpahan yang jauh lebih tinggi, area lamun juga memiliki struktur komposisi yang lebih bervariasi dibanding area makroalga. Similaritas antar stasiun pada area lamun berkisar antara $58-79 \%$, sedangkan pada makroalga berkisar antara 71-77\%. Hal ini juga ditunjukkan oleh adanya dua kelompok berbeda di dalam satu area lamun, yaitu kelompok dua dan tiga. Sedangkan di area makroalga hanya ada satu kelompok 


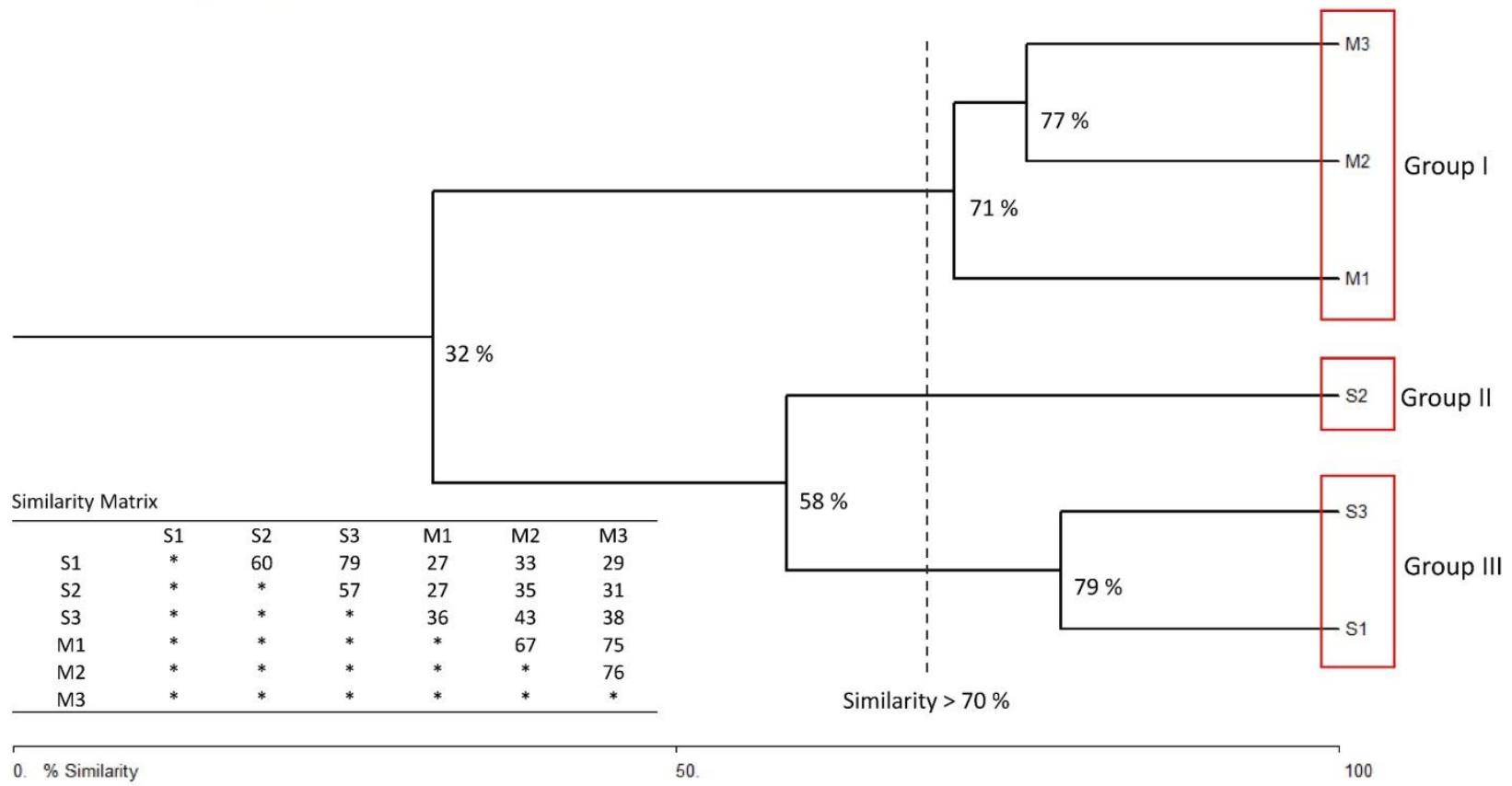

Gambar 3. Analisis klastering struktur komposisi genus-genus dinoflagellata bentik target di area penelitian. Catatan: $\mathrm{S}$ = seagrass / lamun, $\mathrm{M}=$ makroalga.

Figure 3. Clustering analysis of structure composition of targeted benthic dinoflagellate genus in the research area. Note: $\mathrm{S}=$ seagrass / seagrass, $\mathrm{M}=$ macroalgae.

\section{Analisis Parameter Lingkungan}

Area penelitian yang didominasi lamun memiliki kadar nutrien lebih tinggi dibanding makroalga, meskipun perbedaanya tidak terlalu tinggi. Kandungan nitrogen dan fosfat pada ekosistem lamun rata-rata 8,29 dan $4,50 \mathrm{ppm}$, sedangkan di area makroalga 6,59 dan 5,33 ppm. Rasio nitrogen dan fosfat (N:P) pada ekosistem lamun dan makroalga masing masing 1,85 dan 1,25 . Suhu perairan di masing-masing stasiun diketahui memiliki nilai hampir sama, yaitu berkisar $24-24,2{ }^{\circ} \mathrm{C}$. Suhu perairan di area lamun rata-rata sebesar $24,07{ }^{\circ} \mathrm{C}$, sedangkan di area makroalga $24{ }^{\circ} \mathrm{C}$. Kadar nutrien dan suhu yang relatif tidak tinggi perbedaannya disebabkan karena stasiun-stasiun tersebut masih berada di satu area yang relatif tidak terlalu luas sehingga jarak antar stasiun relatif dekat, yakni kurang dari 500 meter.

Tabel 2. Konsentrasi nutrien (N, P), rasio N:P, dan suhu di tiap stasiun sampling pada penelitian ini. Table 2. The concentration of nutrients (Nitrogen, Phosphate), N:P ratio, and water temperature at each sampling station.

\begin{tabular}{ccccc}
\hline Station & $\mathrm{N}$ & $\mathrm{P}$ & $\mathrm{N}: \mathrm{P}$ & Temperature \\
\hline S 1 & 7.94 & 4.67 & 1.70 & 24.0 \\
S 2 & 8.54 & 4.67 & 1.83 & 24.2 \\
S 3 & 8.39 & 4.15 & 2.02 & 24.0 \\
M 1 & 5.38 & 6.02 & 0.89 & 24.0 \\
M 2 & 8.70 & 5.44 & 1.60 & 24.0 \\
M 3 & 5.68 & 4.54 & 1.25 & 24.0 \\
\hline Average & 7.49 & 4.67 & 1.61 & 24.03 \\
Avg. Seagrass & $\mathbf{8 . 2 9}$ & 4.50 & $\mathbf{1 . 8 5}$ & 24.07 \\
Avg. Macroalgae & 6.59 & $\mathbf{5 . 3 3}$ & 1.25 & 24.0 \\
\hline
\end{tabular}

Analisis korelasi kelimpahan genus-genus dinoflagellata bentik terhadap parameter lingkungan menunjukkan korelasi sedang hingga kuat terhadap kelimpahan total genus-genus (Tabel 3). Korelasi paling tinggi ditunjukkan oleh parameter rasio nitrogen-fosfat $(0,74)$, sedangkan korelasi paling rendah ditunjukkan oleh parameter fosfat $(-0,55)$. Parameter nitrogen menunjukkan nilai korelasi positif sedangkan parameter fosfat menunjukkan nilai korelasi negatif terhadap 
Firdaus et al.

kelimpahan total. Berdasarkan konsep rasio nitrogen-fosfat, nilai-nilai tersebut menunjukkan bahwa parameter nitrogen merupakan faktor pembatas yang mengontrol kelimpahan genusgenus target. Hal ini didukung oleh data rasio nitrogen-fosfat yang relatif kecil (rata rata 1,6) di semua stasiun penelitian. Berdasarkan rasio atom nitrogen dan fosfat yang diperkenalkan oleh Alfred Clarence Redfield, rasio nitrogen-fosfat yang dapat mendukung penyerapan nutrisi oleh fitoplankton adalah 16:1. Nilai tersebut berbeda jauh dengan nilai $\mathrm{N}: \mathrm{P}$ dalam penelitian ini atau 10 kali lebih kecil dari rasio Redfield.

Tabel 3. Matriks korelasi antar genus target, parameter biotik (densitas sel), parameter fisik (suhu), dan parameter kimia (nutrien). Perhitungan nilai korelasi berdasarkan indeks korelasi Pearson.

Table 3. Pearson's Correlation matrix between targeted genus, biotic parameters (cell density), physical parameters (temperature), and chemical parameters (nutrients).

\begin{tabular}{c|cccccccccc}
\hline & Amp. & Coo. & Gam & Ost. & Pro. & Density & Temp. & $N$ & $P$ & $N: P$ \\
\hline Amp. & 1.00 & & & & & & & & \\
Coo. & 0.53 & 1.00 & & & & & & & \\
Gam. & 0.41 & 0.90 & 1.00 & & & & & & \\
Ost. & -0.38 & -0.44 & -0.16 & 1.00 & & & & & \\
Pro. & 0.19 & 0.56 & 0.19 & -0.56 & 1.00 & & & & \\
Density & 0.46 & 0.99 & 0.88 & -0.39 & 0.63 & 1.00 & & & \\
Temp. & 0.31 & 0.68 & 0.93 & 0.11 & -0.19 & 0.64 & 1.00 & & \\
N & 0.48 & 0.59 & 0.50 & 0.20 & 0.46 & 0.65 & 0.36 & 1.00 & \\
P & -0.62 & -0.60 & -0.34 & 0.39 & -0.51 & -0.55 & -0.18 & -0.40 & 1.00 & \\
N:P & 0.71 & 0.72 & 0.53 & -0.12 & 0.58 & 0.74 & 0.33 & 0.90 & -0.75 & 1.00 \\
\hline Value (+/ -) & 0 & $0<1.9$ & $2.0<3.9$ & $4.0<5.9$ & $6.0<7.9$ & $8.0<1.0$ \\
Color & & & & & & & \\
Correlation & No Correlation & Very Weak & Weak & Moderate & Strong & Very Strong \\
\hline
\end{tabular}

Sama seperti hasil analisis korelasi, Analisis Komponen Utama (Principal Component Analysis) juga mengindentifikasi adanya pengaruh parameter nutrien terhadap kelimpahan dinoflagellata di lokasi penelitian (Gambar 4). Namun, hasil Analisis Komponen Utama lebih jauh dapat mengungkap adanya perbedaan parameter nutrien yang paling berpengaruh di masing-masing area penelitian. Berdasarkan analisis AKU, diketahui bahwa habitat lamun di Pulau Pari pada penelitian ini dicirikan dengan perairan dengan suhu yang relatif lebih tinggi dan $\mathrm{N}: \mathrm{P}$ rasio yang juga lebih tinggi dibandingkan dengan habitat makroalga (Gambar 4). Lebih tingginya nilai rasio $\mathrm{N}: \mathrm{P}$ di habitat lamun menunjukkan bahwa ketersediaan nitrogen $(\mathrm{N})$ di perairan tersebut lebih baik dibandingkan dengan di habitat makroalga. Sebaliknya, habitat makroalga di Pulau Pari dicirikan dengan perairan sekitar yang lebih kaya akan fosfor (P) (Gambar 4). Sebagai catatan, dari tiga titik pengambilan sampel di habitat lamun, satu titik (S2) memiliki karakter perairan yang cukup jauh berbeda dengan dua titik lainnya (S1 dan S3) (Gambar 3), yang terutama dikarenakan perbedaan suhu perairan dan rasio $\mathrm{N}: \mathrm{P}$ di $\mathrm{S} 2$ yang cukup jauh dibandingkan dengan S1 dan S3 (Gambar 4). 

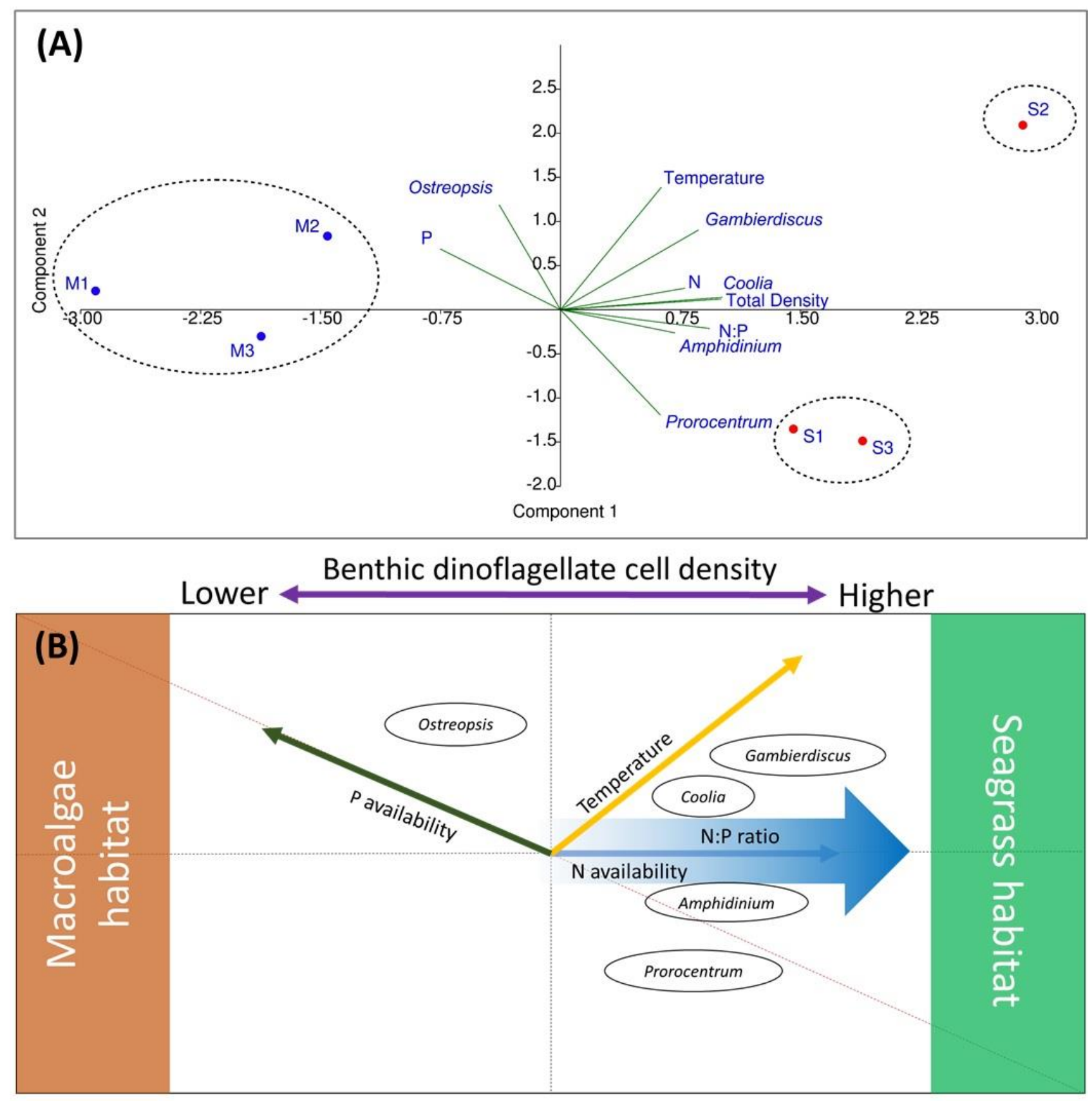

\section{$\mathrm{N}: \mathrm{P}$ ratio}

$\mathrm{N}: \mathrm{p}$ ratio

Gambar 4. Grafik biplot (A) Analisis Kelompok Utama dan (B) diagram skematik yang menunjukkan asosiasi kelimpahan genus dinoflagellata bentik target dan parameter lingkungan di lokasi penelitian.

Figure 4. Biplot graphs of (A) Principal Component Analysis (PCA) and (B) schematic diagram showing the association between dinoflagellates cell density and environmental parameters at the study sites.

\section{Pembahasan}

\section{Perbandingan densitas dinoflagellata bentik pada habitat lamun dan makroalga}

Secara umum hasil penelitian menunjukkan bahwa kelimpahan dan komposisi lima genus dinoflagellata bentik yang ada di habitat lamun berbeda dengan yang ada di habitat makroalga. Hal tersebut diduga disebabkan oleh perbedaan kandungan nutrien, terutama nilai rasio nitrogen-fosfat, antara dua habitat kajian dalam penelitian ini. Hasil analisis korelasi menunjukkan bahwa kelimpahan paling berkorelasi dengan parameter $\mathrm{N}: \mathrm{P}(0,74)$, diikuti oleh nitrogen $(0,67)$ dan fosfat $(-0,55)$. Untuk suhu, meskipun nilai korelasinya 0,63 , namun diduga hal tersebut bukan faktor utama. Hal ini dikarenakan area penelitian yang relatif kecil tidak menyebabkan adanya variasi suhu yang berarti. Selisih suhu rata-rata pada ekosistem lamun dan makroalga hanya sebesar $0,07{ }^{\circ} \mathrm{C}$. Hasil analisis komponen utama juga mengindentifikasi adanya pengaruh 
yang kuat dari tingginya rasio $\mathrm{N}: \mathrm{P}$ terhadap kelimpahan beberapa genus target, yaitu Gambierdiscus, Coolia, Prorocentrum, dan Amphidinium. Selain itu, nilai rasio N:P pada ekosistem lamun yang lebih tinggi dibanding makroalga mengindikasikan bahwa ketersediaan nitrogen pada ekosistem makroalga lebih terbatas dibanding lamun. Hal tersebut juga dapat terlihat dari nilai nitrogen yang lebih tinggi pada ekosistem lamun dan nilai fosfat yang lebih tinggi pada makroalga. Nilai N:P yang rendah $(<16)$ juga menunjukan bahwa nitrogen merupakan faktor pembatas di area studi. Artinya, peningkatan unsur nitrogen pada perairan area studi akan diikuti oleh meningkatnya kelimpahan dinoflagellata bentik

Kondisi perairan di habitat lamun yang memiliki ketersediaan nitrogen $(\mathrm{N})$ yang lebih tinggi, serta suhu perairan yang relatif lebih hangat dibandingkan dengan habitat makroalga, tampak lebih disukai oleh Coolia dan Gambierdiscus. Akibatnya, densitas sel kedua genus dinoflagellata tersebut lebih tinggi di habitat lamun Pulau Pari. Di kawasan sub-tropis (temperate), Coolia diketahui sering ditemukan berasosiasi dan memilih berada di substrat berupa lamun, sedangkan di kawasan tropis makroalga merah dari kelompok Florideophyceae sering dipilih sebagai substrat penempelan Coolia (Boisnoir et al., 2019). Dalam penelitian di pesisir Laut Karibia, Boisnoir et al. (2019) menemukan preferensi Coolia dalam menempel dan tumbuh baik di substrat makroalga dari spesies Galaxaura spp., sedangkan genus Gambierdiscus ditemukan dalam densitas tinggi di habitat yang didominasi oleh spesies lamun Halophila stipulacea. Sementara itu, tingginya densitas sel Gambierdiscus seringkali dikaitkan dengan peningkatan suhu perairan di kawasan sub-tropis dan dinamika suhu menjadi faktor penting dalam menentukan tingkat diversitas dinoflagellata bentik di dasar suatu perairan (Boisnoir et al., 2019).

Meskipun ekosistem makroalga memiliki nilai $\mathrm{N}$ dan rasio $\mathrm{N}: \mathrm{P}$ lebih rendah dibanding lamun, namun nilai $\mathrm{P}$ yang lebih tinggi pada ekosistem makroalga dapat dimanfaatkan oleh genus Ostreopsis. Ostreopsis merupakan satusatunya genus yang ditemukan lebih melimpah pada ekosistem makroalga dibandingkan pada lamun. Kelimpahan genus Ostreopsis yang relatif tinggi pada ekosistem makroalga diduga disebabkan oleh ketersediaan fosfat yang lebih tinggi di perairan tersebut. Hal ini didasarkan pada hasil Analisis Kelompok Utama (AKU) yang menunjukkan bahwa fosfat merupakan faktor yang relatif berpengaruh (positif) paling kuat 200 terhadap Ostreopsis dibanding parameter lainnya. Selain itu, ekosistem makroalga yang dikaji dalam penelitian ini berada di rataan terumbu yang dekat dengan zona pecah ombak, yang mana area tersebut memiliki kondisi perairan yang relatif lebih turbulen dibandingkan dengan ekosistem lamun yang berada di dalam laguna. Kondisi perairan yang turbulen atau memiliki pergerakan air yang relatif tinggi ("stirred waters") lebih disukai oleh genus Ostreopsis (Fraga et al., 2012). Sementara itu, aktivitas ombak dan arus, atau pergerakan air yang tinggi diketahui sangat berpengaruh dalam membatasi atau menurunkan densitas sel dinoflagellata bentik di perairan. Sehingga densitas sel dinoflagellata, terutama yang tergolong dalam kategori penghasil racun (toxic dinoflagellate), diketahui lebih tinggi di habitat-habitat yang terlindung dari aktivitas ombak (Okolodkov et al., 2007). Dalam penelitian ini, habitat lamun yang berada di dalam laguna yang terlindung dari turbulensi kuat akibat ombak dan arus, diduga lebih mendukung untuk penempelan dan kehidupan dinoflagellata bentik di habitat lamun. Hal tersebut menyebabkan densitas selnya jauh lebih tinggi dibandingkan dengan di habitat makroalga yang berada di rataan karang dekat zona pecah ombak (wave breaking zone).

Komposisi genus dinoflagellata target di area habitat lamun sangat berbeda dengan yang ditemukan pada habitat makroalga. Hal tersebut ditunjukkan dari tingkat similaritas komposisi genus dinoflagellata target antara kedua habitat tersebut yang hanya sebesar $32 \%$ saja. Perbedaan tersebut timbul terutama karena kehadiran Amphidinium, yang hanya ditemukan pada habitat lamun. Amphidinium merupakan genus dinoflagellata bentik yang anggota spesiesnya, seperti Amphidinium carterae dan Amphidinium klebsii, diketahui dapat menghasilkan senyawa toksik dan dapat menyebabkan Ciguatera Fish Poisoning (CFP) pada manusia (Faust et al., 2009; Potisarn et al., 2017). Di sekitar Kepulauan Seribu, kehadiran genus Amphidinium juga dilaporkan dalam penelitian Razi et al. (2014) di Pulau Harapan. Namun berbeda dengan penelitian ini, genus Amphidinium di Pulau Harapan hanya dapat ditemukan di lokasi yang memiliki substrat dasar pasir (Razi et al. 2014).

\section{Perbedaan densitas dinoflagellata bentik Gambierdiscus, Ostreopsis, dan Prorocentrum di habitat lamun laguna Pulau Pari menurut waktu penelitian}

Berdasarkan hasil penelitian pada 2019 ini, dan penelitian Widiarti \& Anggraini, (2012) dan Anggraeni et al. (2013), diketahui bahwa densitas 
dinoflagellata bentik, terutama dari genus Gambierdiscus, Ostreopsis, dan Prorocentrum di Pulau Pari mengalami fluktuasi namun cenderung meningkat dari tahun ke tahun. Prorocentrum, yang merupakan taksa paling umum yang ditemukan di berbagai tipe substrat di Pulau Pari pada 2013, diketahui hanya memiliki densitas tertinggi sebesar $729,6 \mathrm{sel} / 100 \mathrm{~cm}^{2}$ (Thoha et al., 2020), yang mana jumlah tersebut jauh lebih rendah dari yang ditemukan di penelitian ini, yaitu sebesar $5.309 \mathrm{sel} / 100 \mathrm{~cm}^{2}$. Namun demikian, penelitian pada tahun 2012 oleh Anggraeni et al. (2013) menunjukkan bahwa densitas Prorocentrum pada ekosistem lamun yang berada di stasiun penelitian laguna Pulau Pari (stasiun 13) berkisar antara $16-60 \mathrm{sel} / \mathrm{cm}^{2}( \pm 1.600-6.000$ $\mathrm{sel} / 100 \mathrm{~cm}^{2}$ ). Pada tahun yang sama, yaitu 2012 , Widiarti \& Anggraeni (2012) melaporkan bahwa densitas total genus Prorocentrum di area laguna Pulau Pari adalah sebesar $59 \mathrm{sel} / \mathrm{cm}^{2} \quad( \pm 5.900$ $\mathrm{sel} / 100 \mathrm{~cm}^{2}$ ).

Serupa dengan Prorocentrum, densitas sel Gambierdiscus di Pulau Pari pada penelitian 2019 ini juga diketahui mengalami peningkatan drastis, yaitu sebesar $5.309 \mathrm{sel} / 100 \mathrm{~cm}^{2}$. Pada penelitian tahun 2013 Gambierdiscus diketahui hanya memiliki densitas 50 kali lebih rendah dibandingkan dengan yang ditemukan pada penelitian pada 2019 (Thoha et al., 2020). Rendahnya densitas Gambierdiescus pada ekosistem lamun di laguna Pulau Pari juga dilaporkan oleh Anggraeni et al. (2013), yang mana genus tersebut hanya ditemukan di 1 titik pengambilan sampel (Stasiun 1) dengan densitas hanya sebesar $1 \mathrm{sel} / \mathrm{cm}^{2}\left( \pm 100 \mathrm{sel} / 100 \mathrm{~cm}^{2}\right)$.

Berbeda dengan Prorocentrum dan Gambierdiscus, densitas sel Osteropsis ditemukan berfluktuasi dalam beberapa tahun. Ostreopsis pada penelitian ini (2019) ditemukan lebih rendah, yaitu dengan densitas tertinggi sebesar 641 sel $/ 100 \mathrm{~cm}^{2}$, sedangkan densitas tertinggi dinoflagellata tersebut pada tahun 2013 diketahui sebesar $1.386 \mathrm{sel} / 100 \mathrm{~cm}^{2}$ (Thoha et al. 2020). Ostreopsis, pada habitat lamun laguna Pulau Pari tahun 2012 memiliki densitas total yang berkisar antara $\quad 1-4 \quad \mathrm{sel} / \mathrm{cm}^{2} \quad\left( \pm 100-400 \quad \mathrm{sel} / 100 \mathrm{~cm}^{2}\right)$ (Widiarti \& Anggraeni, 2012; Anggraeni et al., 2013).

Penambahan densitas dinoflagellata bentik hingga beberapa kali lipat pada selang waktu 6-7 tahun (2012/2013 dan 2019) di Pulau Pari, terutama untuk genus Gambierdiscus, merupakan fenomena yang menarik untuk dikaji namun memiliki konsekuensi negatif terhadap ekosistem pesisir di pulau tersebut. Genus Gambierdiscus dikenal memiliki anggota jenis yang sering mengalami ledakan populasi (blooming) dan merupakan penyebab utama kasus CFP di dunia, seperti Gambierdiscus toxicus (Faust et al., 2009). Peningkatan densitas Gambierdiscus di suatu habitat atau ekosistem bentik, seperti pada lamun dan makroalga, dari tahun ke tahun dapat merupakan indikasi adanya gangguan yang mengakibatkan perubahan kondisi lingkungan menjadi lebih sesuai untuk pertumbuhan cepat selsel Gambierdiscus di berbagai tipe substrat di dasar perairan.

Peningkatan densitas Gambierdiscus pada substrat makrofita perairan juga dapat diakibatkan karena berkurangnya tekanan grazing oleh ikanikan yang hidup di sekitar habitat terumbu karang. Eksperimen yang dilakukan oleh Loeffer et al. (2015) di Virgin Island, Amerika Serikat, menunjukkan bahwa grazing oleh ikan secara signifikan dapat menurunkan densitas sel Gambierdiscus yang menempel pada substrat buatan pada penelitian tersebut. Densitas sel Gambierdiscus pada penelitian tersebut diketahui meningkat hingga $374 \%$ di area eksperimen yang mengalami pembatasan dalam proses grazing oleh ikan herbivora (limited grazing) (Loeffer et al., 2015). Oleh karena itu, tekanan grazing yang berkurang pada ekosistem makrofita di Pulau Pari, baik akibat berkurangnya jumlah ikan herbivora atau bergantinya dominasi tipe trofik ikan pada ekosistem tersebut, dapat merupakan salah satu penyebab dari meningkatnya densitas sel Gambierdiscus pada substrat perairan. Keanekaragaman dan jumlah ikan karang dan herbivora, teruama grazer di Pulau Pari sendiri telah mengalami penurunan yang cukup drastis, yaitu dari sejumlah 205 spesies pada 2012 hingga menjadi 121 spesies pada 2014 (Maduppa et al., 2012; Wibowo et al., 2016).

\section{Kesimpulan}

Hasil penelitian secara umum menunjukkan bahwa kelimpahan kelima genus dinoflagellata bentik dalam penelitian ini lebih tinggi di habitat lamun dibandingkan dengan habitat makroalga. Genus Gambierdiscus merupakan dinoflagellata bentik beracun yang paling melimpah di habitat lamun, sedangkan dinoflagellata bentik beracun yang paling melimpah di habitat makroalga adalah Prorocentrum. Genus target lainnya seperti Ostreopsis, ditemukan lebih melimpah di habitat makroalga sedangkan Coolia lebih melimpah di habitat lamun. Amphidinium dalam penelitian ini hanya ditemukan di habitat lamun dan kelimpahannya dipengaruhi kuat oleh tingginya rasio $\mathrm{N}: \mathrm{P}$ di habitat tersebut. Perbedaan kelimpahan sel dan genus dinoflagellata bentik beracun tersebut terkait dengan perbedaan kondisi 
nutrien di kolom air di sekitar habitat makroalga dan lamun. Selain itu, adanya peningkatan densitas beberapa genus dinoflagellata bentik toksik, seperti Gambierdiscus, dalam selang waktu 6-7 tahun di habitat makrofita lamun dan makroalga Pulau Pari merupakan indikasi adanya gangguan pada fungsi ekologis di perairan pesisir pulau tersebut. Tingginya kelimpahan dinoflagellata bentik beracun di kawasan padang juga lamun menunjukkan bahwa area tersebut perlu mendapat prioritas dalam upaya manajemen MAB di Pulau Pari. Selain itu, hasil penelitian ini juga mengindikasikan hubungan antara peningkatan input nitrogen dan rasio $\mathrm{N}: \mathrm{P}$ dan peningkatan populasi dinoflagellata bentik beracun di Pulau Pari sehingga sumber-sumber utama penyumbang nitrogen ke dalam perairan sekitar pulau perlu dikendalikan.. Potensi terjadinya kasus CFP akan menjadi sangat tinggi bila terjadi fenomena MAB dinoflagellata bentik di Pulau Pari, sehingga dapat berdampak negatif terhadap kesehatan masyarakat lokal dan akan berpengaruh juga pada aktivitas pariwisata.

\section{Persantunan}

Kegiatan penelitian didanai oleh kegiatan Coremap CTI - RPKP 2019 yang diselenggarakan oleh Pusat Riset Oseanografi, Badan Riset dan Inovasi Nasional. Ucapan terima kasih kami ucapkan kepada Dr. A'an Johan Wahyudi selaku koordinator kegiatan program RPKP 2019. Dalam penelitian dan penulisan artikel ilmiah ini, Mochamad Ramdhan Firdaus berperan sebagai Kontributor Utama, Arief Rachman berperan sebagai Kontributor Utama serta salah satu pembimbing peneliti untuk kegiatan RPKP 2019, Oksto Ridho Sianturi, Diah Anggraini Wulandari, Hanny Meirinawati, dan Mariana Destila Bayu Intan berperan sebagai kontributor anggota. Edy Endrotjahyo berperan sebagai teknisi untuk membantu teknis kegiatan.

\section{Daftar Pustaka}

Accoroni, S., Pasella, M., Romagnoli, T., Razza E., Totti, C., Thomas, N., \& Ellwood, W. (2018). The role of phosphatase activities during a bloom of Ostreopsis cf. ovata in the northern Adriatic Sea. Proceedings of the 18th International Conference on Harmful Algae 2018. International Society for the Study of Harmful Algae. 30-33.

Accoroni, S., Percopo, I., Cerino, F., Romagnoli, T., Pichierri, S., Perrone, C., \& Totti, C. (2015). Allelopathic interactions between the HAB dinoflagellate Ostreopsis cf. ovata and macroalgae. Harmful Algae, 49, 147155.

https://doi.org/10.1016/j.hal.2015.08.007

Almazán-Becerril, A., Escobar-Morales, S., Rosiles-González, G., \& Valadez, F. (2015). Benthic-epiphytic dinoflagellates from the northern portion of the Mesoamerican Reef System. Botanica Marina, 58, 115-128.

Anggraeni, F., Soedjiarti, T. \& Widiarti, R. (2013). Dinoflagellata Epifitik pada Lamun Enhalus acoroides di Rataan Terumbu Pulau Pari, Kepulauan Seribu. Jurnal Akuatika, 4, 35-45. Retrieved from http://jurnal.unpad.ac.id/akuatika/article/vie $\mathrm{w} / 2616$

Boisnoir, A., Pascal, P.-Y., Cordonnier, S., \& Lemée, R. (2019). Spatio-temporal dynamics and biotic substrate preferences of benthic dinoflagellates in the Lesser Antilles, Caribbean sea. Harmful Algae, 81, 18-29.

De Sylva, D.P. (1994). Distribution And Ecology Of Ciguatera Fish Poisoning In Florida, With Emphasis On The Florida Keys. Bulletin of Marine Science, 54(3), 944-954. Retrieved

from https://www.ingentaconnect.com/content/u mrsmas/bullmar/1994/00000054/00000003/ art00027

Elder, L., \& M. Elbrachter. (2010). The Utermohl method for quantitative phytoplankton analysis. In: Karlson et al. (eds.). Manuals and guides: microscopic and mole-cular methods for quantitative phytoplankton analysis. IOC- UNESCO. Paris, Prancis. 13-20pp

Faust, Maria. A. (2009). Ciguatera-Causing Dinoflagellates in a Coral-reef Mangrove Ecosystem, Belize. Atoll Research Bulletin. 1-32pp. 10.5479/si.00775630.569.1.

Fraga, S., Rodríguez, F., Bravo, I., Zapata, M., \& Marañón, E. (2012). Review of the Main Ecological Features Affecting Benthic Dinoflagellate Blooms. Cryptogamie, Algologie, 33, 171-179. https://doi.org/10.7872/crya.v33.iss2.2011. 171

Hoppenrath, M., Murray, S.A., Chomérat, N., \& Horiguchi, T. (2014). Marine Benthic Dinoflagellates - Unveiling Their Worldwide Biodiversity. Seckenberg Pulishing. Germany.

Kibler, S. R., \& R. W. Litaker. (2012). Protocol 1: Collection of BHAB cells from macroalgae and screens. Manual of GEOHAB International training workshop 
on the ecology and taxonomy of benthic marine dinoflagellates, Malaysia, 21-31 May 2012. pp. 14-20.

Larsen, J. \& N. Mohammad-Noor. (2012). Introduction to benthic dinoflagellates. Presented in GEOHAB International training workshop on the ecology and taxonomy of benthic marine dinoflagellates, Malaysia, 21-31 May 2012.

Litaker, R. W., P. A., Tester, M. W. Vandersea, S. R. Kibler, C. Holland, M. Chinain, M. A. Faust \& M. J. Holmes. (2012). Gambierdiscus taxonomy. Presented in GEOHAB International training workshop on the ecology and taxonomy of benthic marine dinoflagellates, Malaysia, 21-31 May 2012.

Loeffler, C. R., Richlen, M. L., Brandt, M. E., \& Smith, T. B. (2015). Effects of grazing, nutrients, and depth on the ciguateracausing dinoflagellate Gambierdiscus in the US Virgin Islands. Marine Ecology Progress Series, 531, 91-104. https://doi.org/10.3354/meps11310

Madduppa, H. H., Ferse, S. C., Aktani, U., \& Palm, H. W. (2012). Seasonal trends and fish-habitat associations around Pari Island, Indonesia: setting a baseline for environmental monitoring. Environmental biology of fishes, 95, 383-398. https://doi.org/10.1007/s10641-012-0012-7

Marfai, M. A., Sarastika, T., Trihatmoko, E., Rahantan, R., \& Sarihati, P. (2018). Kajian Daya Dukung dan Ekosistem Pulau Kecil: Studi Kasus Pulau Pari. UGM PRESS. Indonesia.

Moreira, A. \& Tester, P. A. (2016). Methods for sampling benthic microalgae. In: B. Reguera, R. Alonso, A. Moreira, S. Mendez and M.-Y. D. Bottein (eds). Guide for Designing and Implementing a Plan to Monitor Toxin-Producing Microalgae ( $2^{\text {nd }}$ ed., pp19-29). United Nations Educational, Scientific, and Cultural Organization (UNESCO), Paris.

Nurfitri, S., Raihan, M., Putri, M. R., Setiawan, A., Gade, M., \& Pohlmann, T. (2018). Environmental assessment of Pari Island towards oil spill using Geographic Information System (GIS): a preliminary study. IOP Conference Series: Earth and Environmental Science, 162, 012008.

Okolodkov, Y. B., Campos-Bautista, G., GárateLizárraga, I., González-González, J. a. G., Hoppenrath, M., \& Arenas, V. (2007). Seasonal changes of benthic and epiphytic dinoflagellates in the Veracruz reef zone,
Gulf of Mexico. Aquatic microbial ecology, 47, 223-237.

https://doi.org/10.3354/ame047223

Potisarn, N., Lirdwitayaprasit, T., Pholpunthin, P., \& Iwataki, M. (2017). Distribution and abundance of benthic dinoflagellates in seagrass areas of the eastern coast of the upper Gulf of Thailand. Paper presented at the Proceedings the 4th National Meeting on Biodiversity Management in Thailand. Udon Thani, Thailand. Retrieved from http://www.biodconference.org/wp-content/ uploads/2018/05/P23-

33_BioD4_Proceeding.pdf

Razi, F., Widiarti, R., \& Yasman. (2014). Spesifisitas Substrat Dinoflagellata Epibentik Penyebab Ciguatera Fish Poisoning di Perairan Pulau Harapan, Kepulauan Seribu. Jurnal Akuatika, 5 (1), 21-29. ISSN 0853-2532. http:// jurnal.unpad.ac.id/akuatika/article/view/370 1

Randall, J. E. (1958). A Review On Ciguatera, Tropical Fish Poisoning, With A Tentative Explanation Of Its Cause. Bulletin of marine Science of Gulf and Carribean, 8, 237-267. Retrieved from https:// www.ingentaconnect.com/content/umrsmas /bullmar/1958/00000008/00000003/art0000 3

Skalar. (2016). The San ${ }^{++}$Continous flow Analyzer User Manual. Skalar Analytical B.V. Breda.

Soliño, L., \& Costa, P. R. (2020). Global impact of ciguatoxins and ciguatera fish poisoning on fish, fisheries and consumers. Environmental Research, 182, 109111.

Tester, P. A., R. W. Litaker, S. R. Kibler \& C. Holland. (2012), May 21-31. Gambierdiscus toxins and hemolytic activity. The paper presented at the GEOHAB International training workshop on the ecology and taxonomy of benthic marine dinoflagellates, Malaysia.

Thoha, H. (2008). Identification Of Some Strains Of Dinoflagellates Based On Morphology And Molecular Analysis. Makara Journal of Sains, 12(2), 69-74. Retrieved from http://journal.ui.ac.id/science/article/viewFi le/497/493

Thoha, H., Adnan, Q., Sidabutar, T., \& Sugestiningsih. (2007). Note On The Occurrence Of Phytoplankton And Its Relation With Mass Mortality In The Jakarta Bay, May And November 2004. Makara Journal of Sains, 11(2), 63-67. 
Firdaus et al.

Retrieved from http:// repository.ui.ac.id/contents/koleksi/2/f6805 ddb1d7a6d3269a5363693447b0da5d587ce. pdf

Thoha, H., Rachman, A., Intan, M. D. B., \& Usup, G. (2020). Study on The Potentially Harmful Benthic Dinoflagellates in Pari Island, Indonesia. Majalah Ilmiah Biologi BIOSFERA: A Scientific Journal, 37(1), 2735. Retrieved from https:// journal.bio.unsoed.ac.id/index.php/biosfera/ article/view/835

Wibowo, K., Abrar, M., \& Siringoringo, R. M. (2016). Status trofik ikan karang dan hubungan ikan herbivora dengan rekrutmen karang di perairan Pulau Pari, Teluk Jakarta. Oseanologi dan Limnologi di Indonesia, 1(2) , 73-89. https://doi.org/10.14203/oldi.2016.v1i2.85

Widiarti, R. (2002). Dinoflagellata Epibentik Pada Makroalga Di Rataan Terumbu Pulau Penjaliran Barat, Teluk Jakarta. Sains Indonesia, 7(1), 1-9. Retrieved from http://lontar.ui.ac.id/detail?id=89115\&lokas $\mathrm{i}=$ lokal
Widiarti, R. (2007). Dinoflagellata Bentik Penyebab Ciguatera Fish Poisoning Di Rataan Terumbu Karang Pulau Pramuka, Kepulauan Seribu. Jurnal Pasca Panen Perikanan. 17 (1), 1-5

Widiarti, R., \& Anggraini, F. (2012). Distribusi Dinoflagellata Toksik Pada Lamun Enhalus acoroides di Perairan Pulau Pari, Kepulauan Seribu. Jurnal Ilmu dan Teknologi Kelautan Tropis, 4, 259-266. Retrieved from http://www.pksdmo.lipi.go.id/HASILPENELITIAN/EkosistemLaut_2650_51/Distribusi-DinofagelataToksik-Pada-Lamun-Enhalus-acoroides-DiPerairan-Pulau-Pari-Kepulauan-Seribu.html

Widiarti, R., \& Pudjiarto, R. K. (2015). Dinoflagellata Toksik Penyebab Ciguatera Fish Poisoning di Perairan Pulau Tidung, Kepulauan Seribu. BioWallacea, Jurnal Ilmiah Ilmu Biologi, 1 (1), 5-8. Retrieved from

https://www.researchgate.net/publication/29 1274321_Dinoflagellata_Toksik_Penyebab _Ciguatera_Fish_Poisoning_di_Perairan_P ulau_Tidung_Kepulauan_Seribu 